\title{
The simultaneous effect of moisture and pyrite on coal spontaneous combustion using CPT and R7o test methods
}

The Mining-Geology-Petroleum Engineering Bulletin UDC: $536.5 ; 658.5$

DOI: $10.17794 / \operatorname{rgn} .2019 \cdot 3 \cdot 1$

Original scientific paper

\author{
Amir Saffari ${ }^{{ }^{*}}$; Farhang Sereshki ${ }^{1}$; Mohammad Ataei ${ }^{1}$ \\ ${ }^{1}$ Faculty of Mining, Petroleum \& Geophysics Engineering, Shahrood University of Technology, Shahrood, Iran.
}

\begin{abstract}
Among fossil fuels, coal is the most widely used all over the world for generating power and electricity and it is a stable source of energy. Despite all these benefits, coal mining has serious hazards, such as coal spontaneous combustion. There are many factors that influence the tendency for coal to spontaneously combust in coal mines. Pyrite can promote the risk of this phenomenon. This promotion is accelerated by the combination of pyrite and moisture content at the same time. This combination is very rarely discussed in literature. So, in this research, the accelerating effect of reactive pyrite and moisture content on coal spontaneous combustion was measured experimentally using crossing point temperature (CPT) and R7o test methods. For this purpose, a new experimental apparatus was assembled and made in Iran. Reaction rate data obtained from the experimental results showed that pyrite has a twofold action. It first catalyzes the oxidation reaction. Then, in a moist environment, pyrite is itself oxidized, which provides a secondary heat source, and so accelerates the process of coal spontaneous combustion. Since the pyrite oxidation reaction consumes moisture, there is a mutual effect of accelerated heating as less heat is used up in moisture evaporation. The results show that pyrite content can linearly accelerate the coal spontaneous combustion process, while moisture content under $20 \%$ increases it, and if the moisture exceeds $20 \%$, the rate of this process is reduced. The results of this research are helpful in the assessment and management of coal spontaneous combustion issues in coal mines.
\end{abstract}

Keywords:

Coal Spontaneous Combustion, Moisture, Pyrite, CPT Method, R7o Method.

\section{Introduction}

Fossil fuels contain about $90 \%$ of the proven reserves of global energy. Nowadays, coal is a major component and it is the most plentiful and economical fossil fuel including nearly $90 \%$ of the fossil fuel energy around the world, which meets growing energy requirements in many countries, and thereby, coal makes up a large portion of economic growth (Saffari et al., 2013; Thakur et al., 2014; Sereshki et al., 2016; Ghanbari et al., 2018; Medunić et al., 2018). Over the past 250 years, it has played a vital and fundamental role in the development and stability of the world economy.

Regardless of all its benefits, coal mining is a very intricate system and process. The harsh working conditions and the hazardous environment are the most important factors that affect the coal mining process. The hazards of underground mining are critical parameters, which should be considered in the design and planning phase of coal mining. Some significant hazards in underground coal mining can be summarized as subsidence, outburst, and spontaneous combustion. Therefore, it is necessary to accurately identify the risks involved and to

Corresponding author: Amir Saffari

amirsaffari5710@yahoo.com find ways to forecast, prevent, and control them (Saffari et al., 2017).

Coal is a burning material, which is applicable to a variety of oxidation scenarios with conditions ranging from the atmospheric temperature to the ignition temperature. "Spontaneous combustion," which is also called "coal self-heating,", "coal self-burning" and "coal self-ignition" events are disasters triggered by both natural and human factors and may occur in underground coal beds, coal gangue dumps, coal piles, and abandoned mines (Yuan and Smith, 2012; Wang and Chen, 2015).

This phenomenon is one of the most frequent and one of the most serious natural disasters in the world's coal industry (Li et al., 1998; Hu and Jiang, 2000; Xian et al., 2001; Xu, 2001; Saffari et al., 2017). It can cause a series of problems, including personal injury, significant environmental contamination, huge economic loss, and temporary or permanent mine closures, (Xuyao et al., 2011; Deng et al., 2015; Saffari et al., 2019).

Many researchers have worked on techniques to determine the mechanism of this phenomenon. The results of their work show that coal spontaneous combustion is an oxidation process that happens without an external heat source and is an extremely complex, dynamic, autoaccelerated physicochemical process, through which 


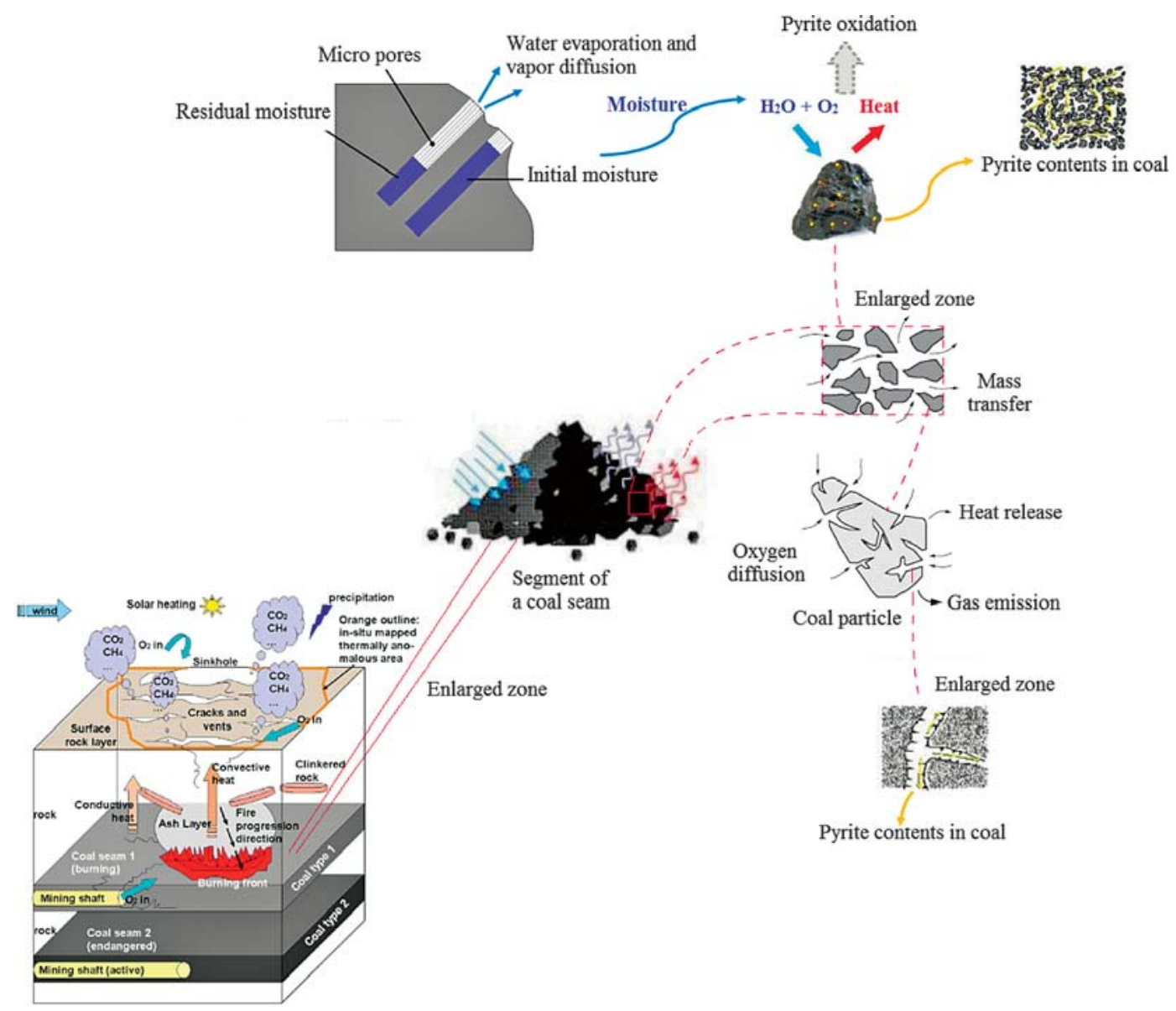

Figure 1: Schematic fundamental phenomena of combination of moisture and pyrite on the coal spontaneous combustion process (modified after Grewer, 1994; Wang et al., 2003; Dijk et al., 2011)

corresponding gas products such as $\mathrm{O}_{2}, \mathrm{CO}, \mathrm{CO}_{2}$, and $\mathrm{CH}_{4}$, are released (Yuan and Smith, 2013; Deng et al., 2015, 2018). This reaction changes the internal heat profile of the material, leading to an increase in temperature. This can eventually lead to an open flame and burning of the material (see Figure 1) (Akgun and Arisoy, 1994; Carras and Young, 1994; Ren et al., 1999; Nugroho et al., 2000; Wang et al., 2003; Smith and Glasser, 2005; Beamish and Arisoy, 2008).

The propensity of coal to spontaneous combustion is an intrinsic property (Wang et al., 2009), which is affected by many parameters. This promotion accelerates with the combination of pyrite and moisture at the same time. It acts as an important foundation for coal spontaneous combustion.

The influence of pyrite and moisture on the process of coal spontaneous combustion has been investigated in a number of studies, which are mentioned in Table 1, and the percentage of studies done on these parameters is shown in Figure 2. Thus, the study of the effects of the pyrite and moisture contents has become increasingly vital in coal spontaneous combustion.

Pyrite is one of the three forms of sulfur, which exist in coal. Pyrites generally show a catalytic effect as their oxidized product accelerates the rate of oxidation of organic compounds present in coal. The pyrite oxidation leads to the formation of ferric ions which catalyzes the reaction, as can be seen in Equations 1 to 4. Also, pyrite oxidation results in swelling, which in turn causes the breakage of coal particles, thus increasing the surface area for enhanced oxidation.

Pyrite plays a vital role in coal spontaneous combustion. The specific heat of pyrite is only one-third of that of coal; but with the same heat absorption, the temperature rise of pyrite is three times higher when compared to coal (Deng et al., 2015). Moreover, pyrite does not react effectively without the presence of moisture and in a dry state, it does not contribute to the thermal runaway process (Arisoy and Beamish, 2015).

Coal with an increasing reactive pyrite content does not reach thermal runaway any faster in a dry state, but in a moist state, it does. So, the key exothermic pyrite reaction takes place with oxygen in the presence of moisture.

Several equations for the reactions of pyrite and oxygen, with the help of moisture are available in literature. For example, the reaction for pyrite oxidation has been given in Equations 1 to 4. 
Table 1: The most famous and important studies about the effect of moisture and pyrite during coal spontaneous combustion

\begin{tabular}{|c|c|c|}
\hline References & Pyrite & Moisture \\
\hline Parr \& Hilgard, 1925 & $\bullet$ & \\
\hline Stott, 1960 & & $\bullet$ \\
\hline Hodges \& Hinsley, 1964 & & $\bullet$ \\
\hline Nandy et al., 1967 & & $\bullet$ \\
\hline Bhattacharyya et al., 1968 & & $\bullet$ \\
\hline Guney, 1971 & & $\bullet$ \\
\hline Bhattacharyya, 1971 & & $\bullet$ \\
\hline Bhattacharyya, 1972 & & $\bullet$ \\
\hline Nandy et al., 1972 & & $\bullet$ \\
\hline Sondreal \& Ellman, 1974 & & $\bullet$ \\
\hline Nordon \& Bainbridge, 1983 & & $\bullet$ \\
\hline Banerjee, 1985 & & $\bullet$ \\
\hline Ghosh, 1986 & $\bullet$ & \\
\hline Li \& Skinner, 1986 & & $\bullet$ \\
\hline Cole et al., 1987 & $\bullet$ & \\
\hline Riley et al., 1987 & $\bullet$ & $\bullet$ \\
\hline Weise et al., 1987 & $\bullet$ & \\
\hline Chandra \& Prasad, 1990 & $\bullet$ & \\
\hline Miron et al., 1992 & $\bullet$ & \\
\hline Chen \& Stott, 1993 & & $\bullet$ \\
\hline Arisoy \& Akgun, 1994 & & $\bullet$ \\
\hline Barve \& Mahadevan, 1994 & & $\bullet$ \\
\hline Bhat \& Agarwal, 1996 & & $\bullet$ \\
\hline Clemens \& Matheson, 1996 & & $\bullet$ \\
\hline Vance et al., 1996 & & $\bullet$ \\
\hline Walters, 1996 & $\bullet$ & \\
\hline Ren et al., 1999 & & $\bullet$ \\
\hline Akgun \& Essenhigh, 2001 & & $\bullet$ \\
\hline Jones, 2001 & & $\bullet$ \\
\hline Panigrahi \& Saxena, 2001 & & $\bullet$ \\
\hline Kadioglu \& Varamaz, 2003 & & $\bullet$ \\
\hline Kucuk et al., 2003 & & $\bullet$ \\
\hline Beamish \& Hamilton, 2005 & & $\bullet$ \\
\hline Beamish et al., 2005 & & $\bullet$ \\
\hline Smith \& Glasser, 2005 & & $\bullet$ \\
\hline Nelson \& Chen, 2007 & $\bullet$ & \\
\hline Singh et al., 2007 & $\bullet$ & $\bullet$ \\
\hline Beamish \& Schultz, 2008 & & $\bullet$ \\
\hline Beamish \& Beamish, 2010 & & $\bullet$ \\
\hline Beamish \& Beamish, 2011 & $\bullet$ & $\bullet$ \\
\hline Wen, 2011 & $\bullet$ & \\
\hline Beamish \& Beamish, 2012 & & $\bullet$ \\
\hline Beamish et al., 2012 & $\bullet$ & \\
\hline Sasaki et al., 2014 & & $\bullet$ \\
\hline Arisoy \& Beamish, 2015 & $\bullet$ & $\bullet$ \\
\hline Beamish \& Theiler, 2015 & & $\bullet$ \\
\hline Deng et al., 2015 & $\bullet$ & \\
\hline Zhang et al., 2016 & & $\bullet$ \\
\hline Zhao et al., 2016 & & $\bullet$ \\
\hline Arisoy et al., 2017 & & $\bullet$ \\
\hline Beamish \& Theiler, 2017 & $\bullet$ & $\bullet$ \\
\hline Yang et al., 2017 & & $\bullet$ \\
\hline Wang et al., 2018 & & $\bullet$ \\
\hline
\end{tabular}

$\mathrm{FeS}_{2}+8 \mathrm{H}_{2} \mathrm{O}+\frac{7}{2} \mathrm{O}_{2} \rightarrow \mathrm{FeSO}_{4} \cdot 7 \mathrm{H}_{2} \mathrm{O}+\mathrm{H}_{2} \mathrm{SO}_{4}$

$(\Delta \mathrm{H}=-1465.49 \mathrm{~kJ})$

(Weise et al., 1987)

$$
\mathrm{FeS}_{2}+8 \mathrm{H}_{2} \mathrm{O}+7 \mathrm{O}_{2} \rightarrow \mathrm{FeSO}_{4} \cdot 7 \mathrm{H}_{2} \mathrm{O}+\mathrm{SO}_{4}{ }^{2-}+2 \mathrm{H}^{+}
$$

(Beamish et al., 2012)

$$
\mathrm{FeS}_{2}+7 \mathrm{O}_{2}+16 \mathrm{H}_{2} \mathrm{O} \rightarrow 2 \mathrm{H}_{2} \mathrm{SO}_{4}+2 \mathrm{FeSO}_{4} \cdot 7 \mathrm{H}_{2} \mathrm{O}+1321 \mathrm{~kJ}
$$

(Arisoy and Beamish, 2015)

$$
\mathrm{FeS}_{2} \stackrel{\mathrm{O}_{2}+\mathrm{H}_{2} \mathrm{O}}{\longrightarrow} \mathrm{FeSO}_{4} \underset{\mathrm{O}_{2}+\mathrm{H}_{2} \mathrm{O}+\mathrm{FeS}_{2}}{\stackrel{\mathrm{O}_{2}+\mathrm{H}_{2} \mathrm{O}}{\rightleftarrows}} \mathrm{Fe}_{2}\left(\mathrm{SO}_{4}\right)_{3}
$$

(Deng et al., 2015)

The above equations suggest that oxygen and moisture are two prime weathering parameters, which contribute to the pyrite alteration shown and it also leads to the formation of sulphuric acid as a by-product of the alteration process. The presence of moisture doubles the reactivity rate of coal and the presence of pyrite in dispersed form 10 folds the actual reaction rate (Mahananda, 2014).

These reactions can occur at low temperatures and additionally, all of the reactions are exothermic reactions. The heat generation from these reactions doubles the amount of heat generated by coal with the same amount of oxygen (Garcia et al., 1999; Martínez et al., 2009). So, the presence of pyrite along with moisture is a big promoter for coal spontaneous combustion and can change the propensity of coal towards spontaneous combustion.

Different countries have adopted different methods to assess the propensity of coals to spontaneous combustion in the laboratory for their applicability. The objective of different entities of mining operations is to assess the hazard of spontaneous combustion and its related risk to ensure the safety of miners and machines.

The criteria for the determination of spontaneous combustion should be the purpose of investigation and its use. Mining planners need information regarding the assessment and prediction of spontaneous combustion prior to design whereas operators need information during mining activity or when moving onto new areas or seams. All of these investigations have attempted to characterize coal samples in the laboratory to identify the mechanisms that govern the susceptibility of a particular coal to spontaneously heat under field conditions. The reliability and repeatability of these test results to its applicability or with field conditions/mechanisms play an important role for the selection of testing methods. Similarly, the cost, duration of an experiment and expertise of the user are of the most concern for different testing methods of spontaneous combustion (Mohalik et al., 2016). A certain amount of instrumental methods and techniques for the characterization of a coal's pro- 
pensity to spontaneous combustion exist. Two of the most important methods are the crossing point temperature (CPT) and R70 test methods, which have been used frequently. CPT and R70 test methods are thermal methods used to determine the tendency of coal spontaneous combustion. This rate of the rise in coal temperature during coal oxidation becomes greater under the appropriate conditions. In this study, in order to comprehensively investigate the influence of pyrite along with moisture on coal spontaneous combustion, characteristics on the acceleration of the coal spontaneous combustion process, temperature-programmed experiments were carried out using CPT and R70 test methods.

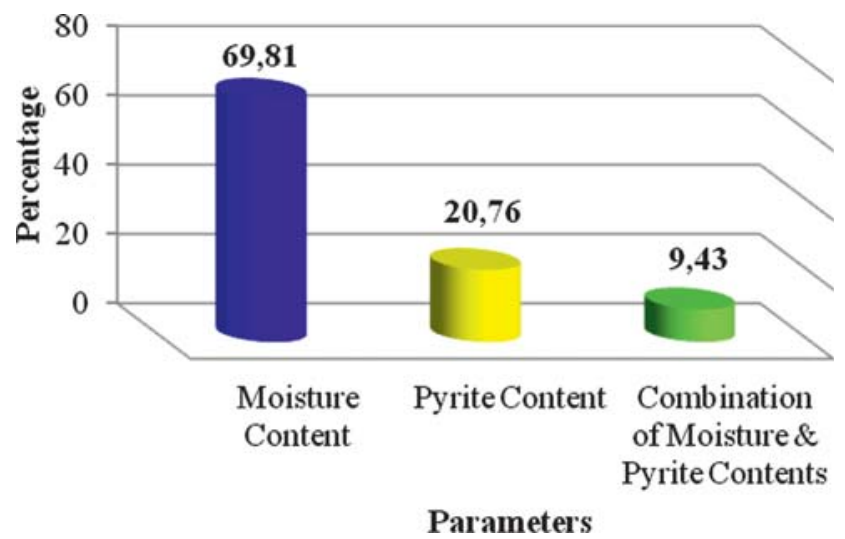

Figure 2: Percentage of studies done on parameters (Moisture, Pyrite and Combination of Moisture and Pyrite) in literature

\section{Materials and methods*}

\subsection{Coal samples and preparation}

In this work, six coal samples (from the Eastern Alborz coal mine) were freshly collected directly from the working face of the mine, after removing a coal seam of approximately $25 \mathrm{~cm}$ thickness. In order to avoid the possibility of peroxidation in the samples, they were sent to an air sealed plastic container that was completely filled with nitrogen and contained approximately $5 \mathrm{~kg}$ of coal, mostly in lump form. The samples were transported to the laboratory in an ice-filled insulated container to avoid peroxidation.

The samples were delivered to the laboratory as rapidly as possible. Upon arrival, the samples were transferred to a freezer for storage until required for testing. In order to minimize unnecessary oxidation, the samples were maintained in lump condition and were kept undisturbed in the laboratory prior to each test. After the test facility was ready, the plastic bag was unwrapped, its surface was removed and its interior core was crushed to obtain the samples. For the CPT test, the coal particles ranging in size from $0.18 \mathrm{~mm}$ to $0.38 \mathrm{~mm}$ were sieved for the experimental procedure. For the R70 test, the coal with particle in sizes of $<212 \mu \mathrm{m}$ were sieved for the experimental procedure. The CPT and R70 test method required $60 \mathrm{~g}( \pm 0.01 \mathrm{~g})$ and $150 \mathrm{~g}( \pm 0.01 \mathrm{~g})$ of crushed coal sample packed in the coal reaction vessel, respectively.

In order to minimize the effects of oxidation on fresh surfaces, coal test samples were ground and prepared just before each trial.

To emphasize the influence of pyrite and moisture on the characteristics of coal spontaneous combustion, samples used in the experiments were mixtures of coal, pyrite and moisture (pyrite and moisture content of coal samples were natural), and the other characteristics were similar, such as, the maceral and pyrite contents in sample No. 6, as shown in Figure 3, using a microscopic image.

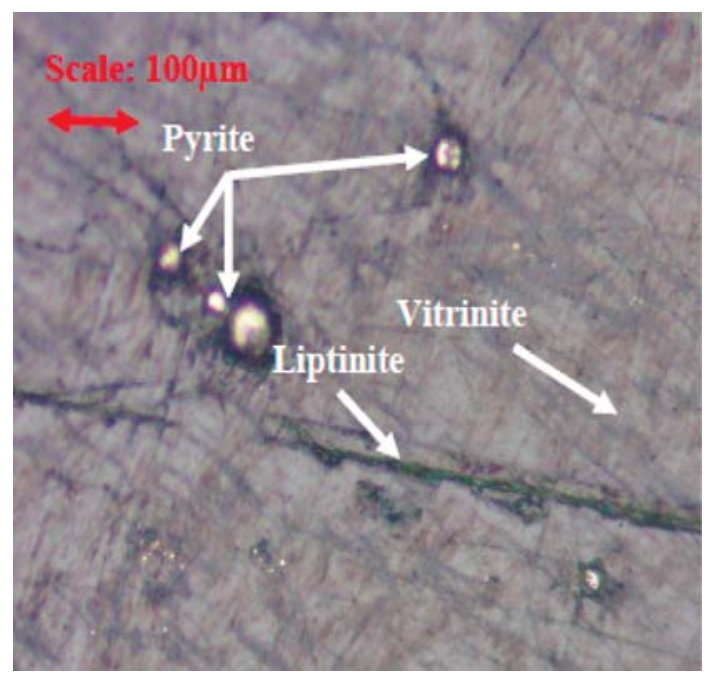

Figure 3: Macerals and minerals found in sample No. 6

\subsection{Experimental apparatus and methods}

A certain amount of instrumental methods and techniques for the characterization of coal propensity to spontaneous combustion exist. Two of the most widely used methods are CPT and R70 test methods. CPT and R70 test methods are thermal methods used to determine coal spontaneous combustion propensity. For the first time in the world, an experimental apparatus which can measure CPT and R70 test methods in separate tests was made in the Shahrood University of Technology in Iran, and this apparatus was used in this research work.

\subsubsection{Crossing point temperature (CPT) method}

The temperature at which the coal temperature begins to exceed the surrounding temperature is the so-called crossing point temperature (CPT) (Xuyao et al., 2011).

The CPT method is a very important way to reveal the mechanism of coal spontaneous combustion and it is still widely used today. In the experiment, a prepared coal sample is placed in a gauze container and the oven temperature is controlled. The progression of temperature with time in the process of a coal's reaction with air 
or oxygen and the oven temperature are recorded. When the coal sample temperature equals the linearly ramped oven temperature, the temperature is called CPT, as shown in Figure 4. CPT is used as an index to classify the propensity of a coal to spontaneous combustion. (Chen, 1991). The CPT method is widely used in India, Turkey, New Zealand South Africa, Poland and China and it has recently been improved (Mohalik et al., 2016).

The essence of this method is as follows. The coal sample is placed in a programmed adiabatic oven being heated at a constant rate. The oven is set to run at a constant temperature of $50^{\circ} \mathrm{C}$, while dry air with oxygen is permitted to flow through the coal reaction vessel at a rate of $50 \mathrm{~mL} / \mathrm{min}$. The temperature logger is used to continuously monitor the coal temperature and the surrounding temperatures. When the coal temperature reaches $50{ }^{\circ} \mathrm{C}$, the oven is set to increase the temperature at a programmed rate of $1{ }^{\circ} \mathrm{C} / \mathrm{min}$ while the flow rate of dry air is maintained at $50 \mathrm{~mL} / \mathrm{min}$. The experiment ends when the coal temperature is higher than the surrounding programmed adiabatic oven. When the coal sample temperature equals the linearly ramped oven temperature, the temperature is called CPT (Nugroho et al., 1998; Xuyao et al., 2011).

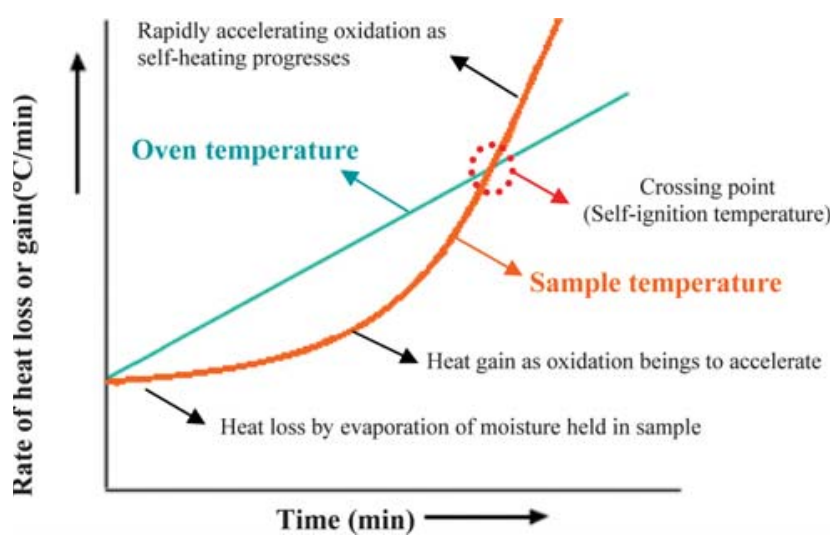

Figure 4: Schematic diagram of crossing point temperature (Kim, 1995)

\subsubsection{R7o method}

The essence of the R70 method is as follows. The ground (with particle sizes of $<212 \mu \mathrm{m}$ ) coal sample is dried in the adiabatic oven at a temperature of 105-110 ${ }^{\circ} \mathrm{C}$ for 16 hours under inert gas flow (nitrogen). Whilst still under nitrogen, the coal is cooled to $40{ }^{\circ} \mathrm{C}$ in the same environment, and after that, it is stored in oxygenrich air flow at a temperature of $40{ }^{\circ} \mathrm{C}$. Under the latter conditions, coal oxidation is being initiated and the processes of self-heating are observed. The average rate of the coal heating from 40 to $70{ }^{\circ} \mathrm{C}$ is considered to be the index R70 $\left({ }^{\circ} \mathrm{C} / \mathrm{h}\right)$. The higher value of such an index, the more prone the coal is to spontaneous combustion. Such a method is the most efficient one with respect to simple characterization of coal propensity to oxidation and selfheating (Beamish et al., 2000, Arisoy and Beamish, 2015).

\subsubsection{Testing system}

Figure 5 shows a schematic diagram of the apparatus applied for the low-temperature oxidation of coal. The testing system consists of an experimental apparatus for the simulation of coal oxidation. The instrument consists of the following, as shown in Figure 6:

- a temperature-programmed adiabatic oven (a temperature-programmed adiabatic oven can set up relevant parameters related to the range and the rise rate of the temperature, and keep the temperature constant. It is applied to control the temperature of the coal samples, whose temperature ranges from room temperature to $400{ }^{\circ} \mathrm{C}$ with a precision of 1 ${ }^{\circ} \mathrm{C}$ in the control);

- an electric heater;

- a fan (used to strengthen and maintain a uniform temperature convection in the oven);

- a coal sample reaction vessel (the coal sample reaction vessel is made of pure aluminum; it has very good thermal conductivity. The coal sample reaction vessel is respectively connected with an inlet for an air supply path, thermocouple for temperature measurement and an outlet for the air outlet path);

- a $15 \mathrm{~m}$ gas pre-heating copper tube (Preheating was achieved by passing the air through a copper tube located inside the programmed adiabatic oven);

- thermocouples (thermocouple 1, fixed at the center of the temperature-programmed adiabatic oven, is used to monitor the surrounding temperature while thermocouple 2, positioned in the middle part of the coal reaction vessel, is used to measure the coal sample temperature);

- JUMO Dicon touch, which consists of:

- a data logger (the temperature changes in the coal sample with time was obtained by a data logging system for later analysis);

- a micro-controller (the programmed adiabatic oven is set to increase the temperature with a micro-controller);

- a computer;

- a $50 \mathrm{~kg} \mathrm{~N}_{2}$ gas cylinder (for preheating of the coal sample for the start test);

- a $50 \mathrm{~kg} \mathrm{O}_{2}$ gas cylinder (the air supply system sends gas into the reaction vessel, and takes gas after the reaction with the coal sample out of the reaction vessel along the exhaust pipe);

- a pressure reducing valve;

- a flow-meter. 


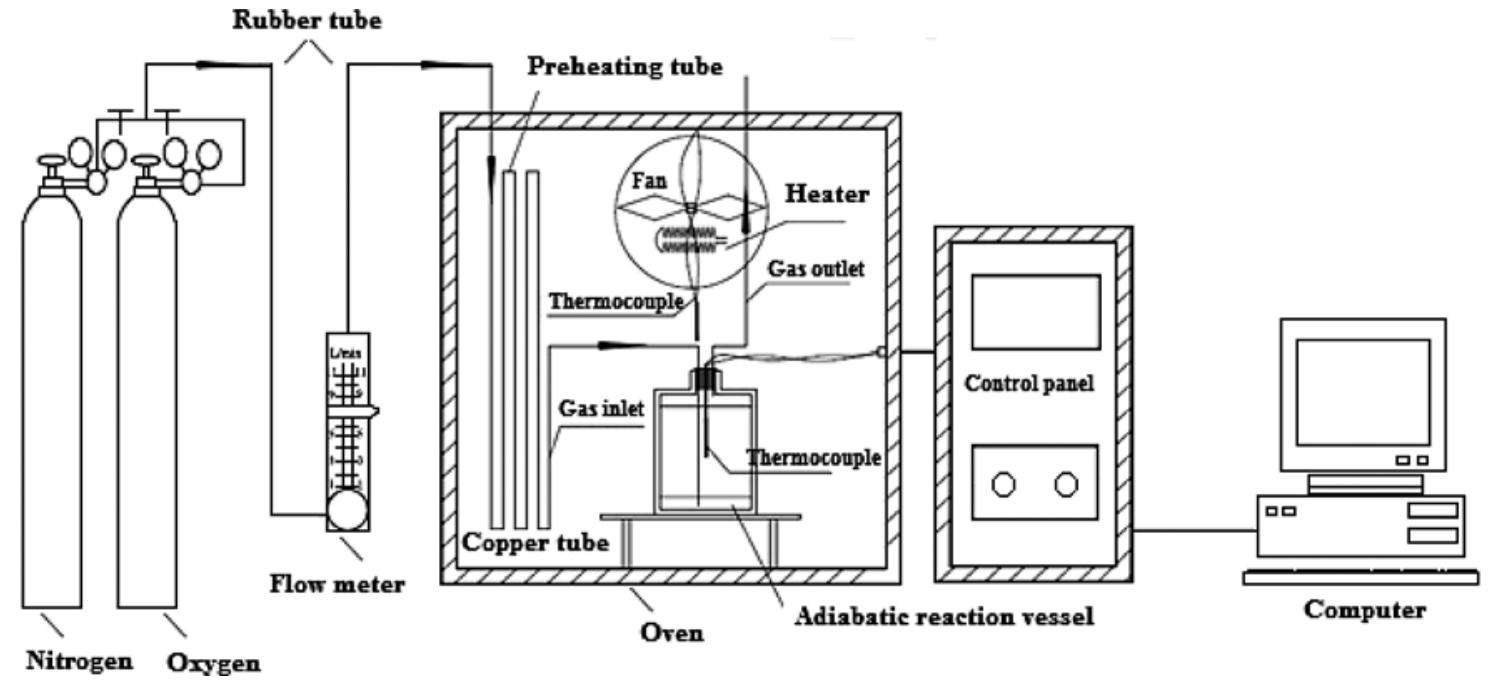

Figure 5: A schematic diagram of the apparatus applied for low-temperature oxidation

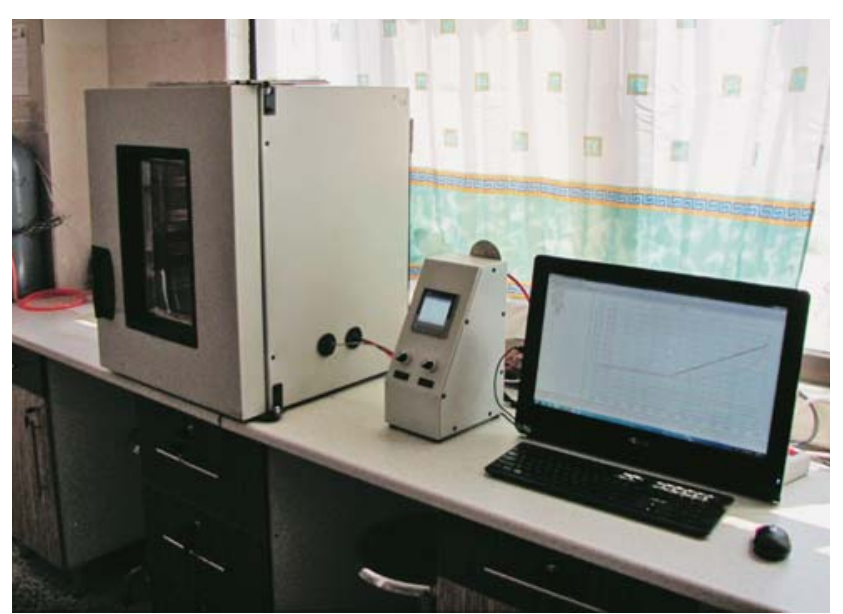

Figure 6: The testing system
Table 2: The coal analytical data for each sample

\begin{tabular}{|l|c|c|c|c|}
\hline $\begin{array}{l}\text { Sample } \\
\text { No. }\end{array}$ & $\begin{array}{c}\text { Moisture } \\
\text { Content }(\%)\end{array}$ & $\begin{array}{c}\text { Pyrite } \\
\text { Content }(\%)\end{array}$ & $\begin{array}{c}\mathrm{CPT} \\
\left({ }^{\circ} \mathrm{C}\right)\end{array}$ & $\begin{array}{c}\mathrm{R} 70 \\
\left({ }^{\circ} \mathrm{C} / \mathrm{h}\right)\end{array}$ \\
\hline$\# 1$ & 0.768 & 0.11 & 190 & 4.27 \\
\hline$\# 2$ & 1.265 & 0.20 & 200 & 2.50 \\
\hline$\# 3$ & 13.288 & 5.30 & 93 & 10.20 \\
\hline$\# 4$ & 32.230 & 1.2 & 195 & 3.95 \\
\hline$\# 5$ & 35.300 & 0.00 & 226 & 1.85 \\
\hline$\# 6$ & 19.950 & 5.7 & 73 & 11.25 \\
\hline
\end{tabular}

\section{Results and discussion}

The curves of CPT and R70 test methods and results for each sample are shown in Figure 7 and Figure 8 as

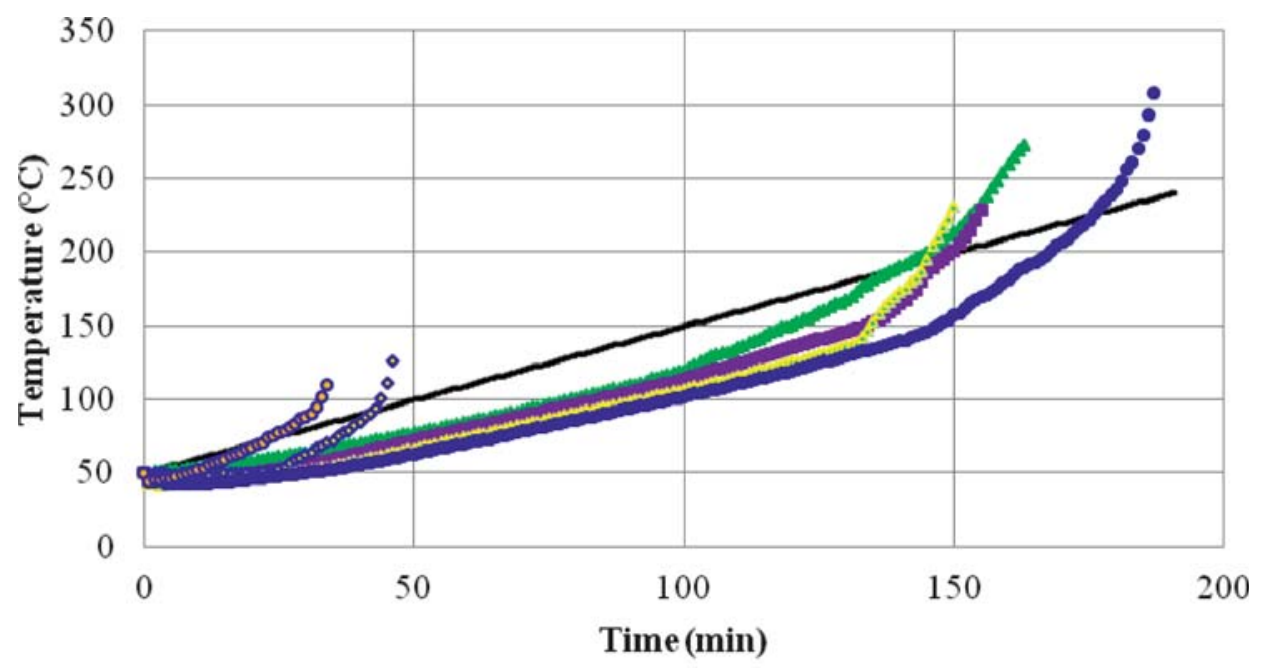

- Oven $\triangle$ Sample 1 -Sample 2 •Sample 3 -Sample 4 •Sample 5 •Sample 6

Figure 7: CPT test results for six different coal samples in terms of moisture and pyrite differences 


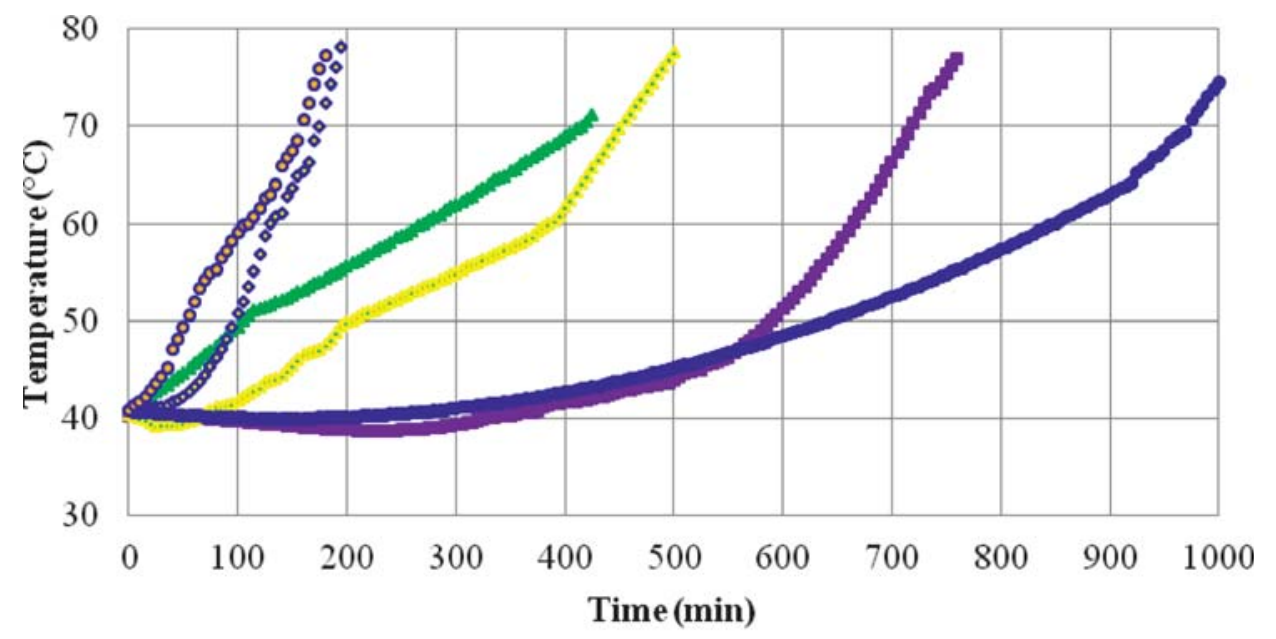

$\Delta$ Sample 1 - Sample 2 -Sample 3 . Sample 4 Sample 5 -Sample 6

Figure 8: R7o test results for six different coal samples in terms of moisture and pyrite differences

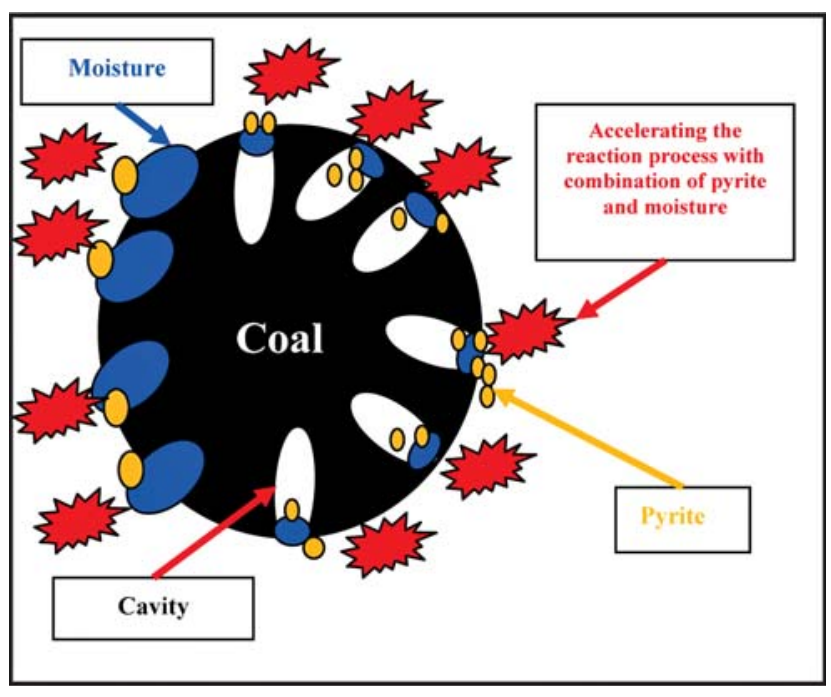

Figure 9: Effect of moisture and pyrite on accelerating the coal spontaneous combustion mechanism

well as Table 2. It can be seen that the coal spontaneous combustion curves are different. This difference is due to the amount of moisture and pyrite contents. Their CPT values for samples are between 73 to $226{ }^{\circ} \mathrm{C}$, and their R70 values for samples are between 1.85 to 11.25 ${ }^{\circ} \mathrm{C} / \mathrm{h}$. Based on the coal moisture and pyrite contents, it could be expected that samples 3 and 6 would have a lower CPT and higher R70 values than the other coal samples. However, the higher pyrite contents and moderate moisture contents of samples 3 and 6 creates a heat effect, compared to the other samples. It must be remembered, that CPT and R70 test for the other samples has a higher and lower value, respectively in comparison to samples 3 and 6 . The reason for this difference is low moisture and low pyrite contents in samples 1 and 2, and high moisture and low pyrite contents in samples 4 and 5. In samples 1 and 2, the amount of moisture and pyrite

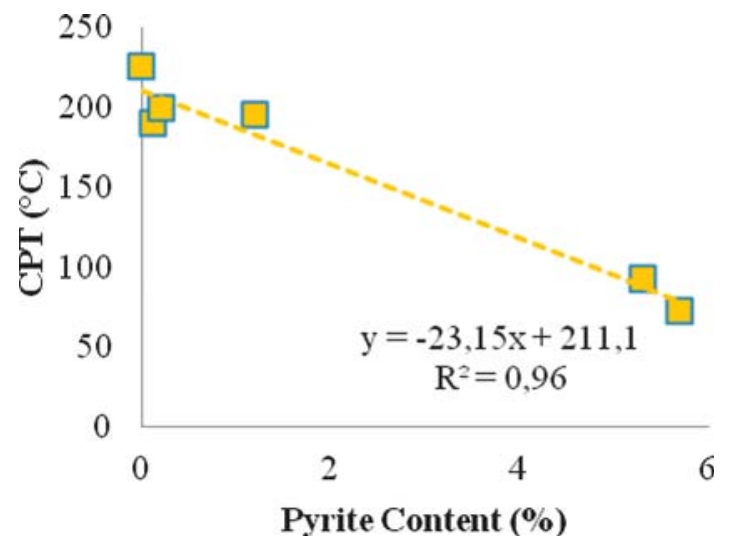

Figure 10: Results of Pyrite Content fit CPT test method

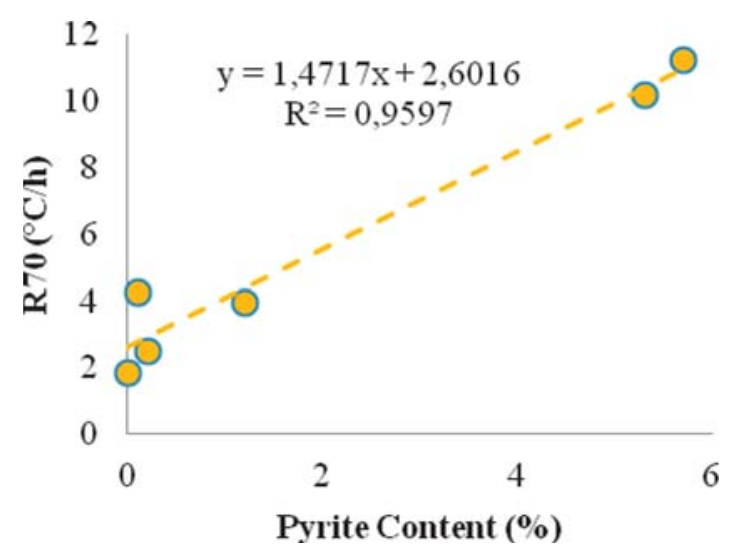

Figure 11: Results of Pyrite Content fit R70 test method

contents is very low and so, the exothermic pyrite oxidation reactions cannot form. In samples 4 and 5, the amount of moisture content is very high, and the heat loss due to moisture evaporation does occur and so, the oxidation mechanism cannot form. As shown in Figure 9, the existence of moisture and pyrite contents on coal 


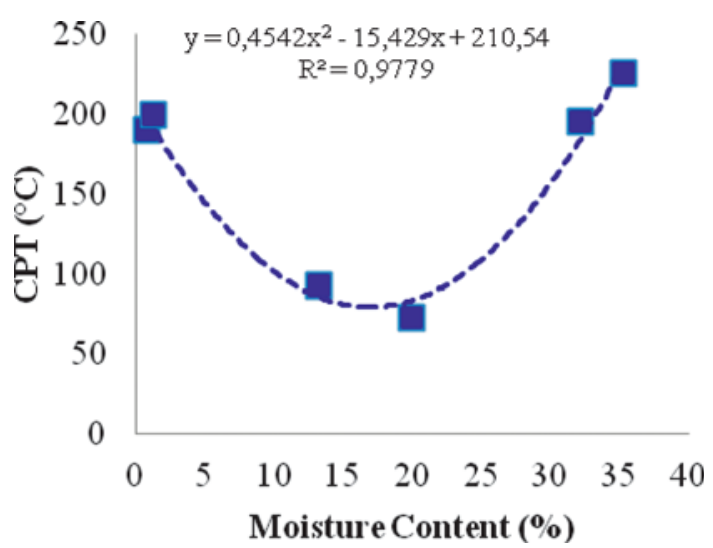

Figure 12: Results of moisture Content fit CPT test method

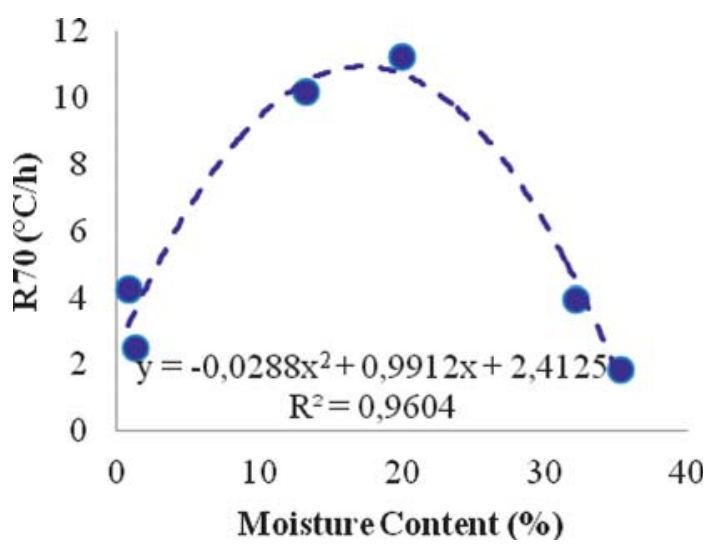

Figure 13: Results of moisture Content fit R7o test method

can accelerate the coal spontaneous combustion mechanism, which is described based on Equations 1 to 4.

According to Equation 2, the existence of moisture and high pyrite content would produce too much $\mathrm{H}^{+}$, which means this reaction is strongly exothermic, and it can be seen that the pyrite oxidation reaction is dependent on the presence of both moisture and oxygen (Beamish et al., 2012).

Thus, samples 3 and 6 follow these equations and the coal spontaneous combustion rates were increased.

Figure 10 and Figure 11 illustrate the impact of pyrite content on coal spontaneous combustion at different values of pyrite contents. The results show pyrite content can linearly accelerate the coal spontaneous combustion process, and it has a positive effect on coal spontaneous combustion.

There are clear distinctions between high moisture content and low moisture content on coal spontaneous combustion behaviours. As long as moisture content is under $20 \%$, coal spontaneous combustion rates increase, which is due to its combination with pyrite, and this is an exothermic process, while it can reduce or restrict the coal spontaneous combustion rates in excess of $20 \%$, which is due to heat loss during moisture evaporation (see Figure 12 and Figure 13). So, the existence of moisture in excess of $20 \%$, can absorb the heat and pre- vent the chemical reactions, which is an endothermic process.

\section{Conclusion}

The coal spontaneous combustion phenomenon is always a big challenge in coal industries, which is affected by many parameters such as pyrite and moisture contents. Despite extensive research carried out on this topic, the mutual effects of moisture and pyrite contents on the rate of coal spontaneous combustion is still not fully understood as stated in literature review. The adiabatic oxidation methods provide significant information on the process of coal spontaneous combustion under conditions close to those found in nature. The simultaneous effects of moisture and pyrite on coal spontaneous combustion using CPT and R70 test methods have been measured experimentally in this study.

The results of this work show that coal spontaneous combustion promotion accelerates with the combination of pyrite and moisture at the same time, so pyrite and moisture contents play an important role. Clearly, the presence of moisture content for the pyrite oxidation reaction is a major parameter in the overall spontaneous combustion propensity of coals containing reactive pyrite.

It is shown that an increase in pyrite content of coal has a marked effect on coal spontaneous combustion. In this research work, coal samples undergo oxidation most rapidly when the moisture content supply is under about $20 \%$, and it can reduce coal spontaneous combustion in excess of $20 \%$, because when moisture is present in excess of $20 \%$, the heat released by oxidation is used to evaporate the moisture. So, at high moisture levels, there is too much water available and the self-heating is hindered by the heat loss from moisture evaporation. Hence the moisture content has a complex behaviour. These differences have practical implications for coal spontaneous combustion management. An applied result of this finding is that improved coal spontaneous combustion measures including pyrite and moisture contents of coal should be taken into account, because their contents can tremendously promote coal spontaneous combustion.

\section{References}

Akgün, F. and Arisoy, A. (1994): Effect of particle size on the spontaneous heating of a coal stockpile. Combustion and Flame, 99, 1, 137-146.

Akgun, F. and Essenhigh, R.H. (2001): Self-ignition characteristics of coal stockpiles: theoretical prediction from a twodimensional unsteady-state model. Fuel, 80, 3, 409-415.

Arisoy, A. and Akgün, F. (1994): Modelling of spontaneous combustion of coal with moisture content included. Fuel, 73, 2, 281-286.

Arisoy, A. and Beamish, B. (2015): Mutual effects of pyrite and moisture on coal self-heating rates and reaction rate data for pyrite oxidation. Fuel, 139, 107-114. 
Arisoy, A., Beamish, B. and Yoruk, B. (2017): Moisture moderation during coal self-heating. Fuel, 210, 352-358.

Banerjee, S.C. (1985): Spontaneous Combustion of Coal and Mine Fires, Dhanbad-India: Central Mining Research Station. Oxford \& IBH Publishing Co. Balkema. Rotterdam, $168 \mathrm{p}$.

Barve, S.D. and Mahadevan, V. (1994): Prediction of spontaneous heating liability of Indian coals based on proximate constituents. In Proceedings $12^{\text {th }}$ International Coal Preparation Congress, 557-562.

Beamish, B. and Beamish, R. (2010): Benchmarking moist coal adiabatic oven testing. Coal Operators' Conference. University of Wollongong. Australia, 264-268.

Beamish, B. and Beamish, R. (2011): Experience with using a moist coal adiabatic oven testing method for spontaneous combustion assessment. Coal Operators' Conference. University of Wollongong. Australia, 380-384.

Beamish, B. and Schultz, T.J. (2008): Moisture content impact on the self-heating rate of a highly reactive subbituminous coal. Coal Operators' Conference. University of Wollongong. Australia, 155-160.

Beamish, B. and Theiler, J. (2015): Contrast in Self-Heating Rate Behaviour for Coals of Similar Rank. Coal Operators' Conference. University of Wollongong. Australia, 300-304.

Beamish, B. and Theiler, J. (2017): Assessing the reactivity of pyrite. Coal Operators' Conference. University of Wollongong. Australia, 391-394.

Beamish, B., Blazak, D.G., Hogarth, L.C. and Jabouri, I. (2005): R70 Relationships and Their Interpretation at a Mine Site. Coal Operators' Conference. University of Wollongong. Australia, 183-185.

Beamish, B., Lin, Z. and Beamish, R. (2012): Investigating the influence of reactive pyrite on coal self-heating. Coal Operators〉 Conference. University of Wollongong. Australia, 294-299.

Beamish, B.B. and Arisoy, A. (2008): Effect of mineral matter on coal self-heating rate. Fuel, 87, 1, 125-130.

Beamish, B.B. and Beamish, R.T. (2012): Benchmarking coal self-heating using a moist adiabatic oven test. In 14th US/ North American Mine Ventilation Symposium.

Beamish, B.B. and Hamilton, G.R. (2005): Effect of moisture content on the R70 self-heating rate of Callide coal. International Journal of Coal Geology, 64, 1-2, 133-138.

Beamish, B.B., Barakat, M.A. and St George, J.D. (2000): Adiabatic testing procedures for determining the self-heating propensity of coal and sample ageing effects. Thermochimica Acta, 362, 1-2, 79-87.

Bhat, S. and Agarwal, P.K. (1996): The effect of moisture condensation on the spontaneous combustibility of coal. Fuel, $75,13,1523-1532$.

Bhattacharyya, K.K. (1971): The role of sorption of water vapour in the spontaneous heating of coal. Fuel, 50, 4, 367-380.

Bhattacharyya, K.K. (1972): The role of desorption of moisture from coal in its spontaneous heating. Fuel, 51, 3, 214-220.

Bhattacharyya, K.K., Hodges, D.J. and Hinsley, F.B. (1968): The influence of humidity on the initial stages of the spontaneous heating of coal. Min. Eng, 126, 274-284.
Carras, J.N. and Young, B.C. (1994): Self-heating of coal and related materials: models, application and test methods. Progress in Energy and Combustion Science, 20, 1, 1-15.

Chandra, D. and Prasad, Y.V.S. (1990): Effect of coalification on spontaneous combustion of coals. International Journal of Coal Geology, 16, 1-3, 225-229.

Chen, X.D. (1991): The Spontaneous Heating of Coal: Large Scale Laboratory Assessment and Supporting Theory: a Thesis Submitted for the Degree of Doctor of Philosophy in Chemical Engineering in the University of Canterbury (Doctoral dissertation, University of Canterbury).

Chen, X.D. and Stott, J.B. (1993): The effect of moisture content on the oxidation rate of coal during near-equilibrium drying and wetting at $50 \mathrm{C}$. Fuel, 72, 6, 787-792.

Clemens, A.H. and Matheson, T.W. (1996): The role of moisture in the self-heating of low-rank coals. Fuel, 75, 7, 891-895.

Cole, D.A., Simmons, G.W., Herman, R.G., Klier, K. and Czakó-Nagy, I. (1987): Transformations of iron minerals during coal oxidation. Fuel, 66, 9, 1240-1248.

Deng, J., Lei, C., Xiao, Y., Cao, K., Ma, L., Wang, W. and Laiwang, B. (2018): Determination and prediction on "three zones" of coal spontaneous combustion in a gob of fully mechanized caving face. Fuel, 211, 458-470.

Deng, J., Ma, X., Zhang, Y., Li, Y. and Zhu, W. (2015): Effects of pyrite on the spontaneous combustion of coal. International Journal of Coal Science \& Technology, 2, 4, 306-311.

Dijk, P.V., Zhang, J., Jun, W., Kuenzer, C. and Wolf, K.H. (2011): Assessment of the contribution of in-situ combustion of coal to greenhouse gas emission; based on a comparison of Chinese mining information to previous remote sensing estimates. International Journal of Coal Geology, 86, 1, 108-119.

Garcia, P., Hall, P.J. and Mondragon, F. (1999): The use of differential scanning calorimetry to identify coals susceptible to spontaneous combustion. Thermochimica acta, 336, $1-2,41-46$.

Ghanbari, K., Ataei, M., Sereshki, F. and Saffari, A. (2018): Determination and assessment of coal bed methane potential using rock engineering systems. Journal of Mining and Environment, 9, 3, 605-621.

Ghosh, R. (1986): Spontaneous combustion of certain Indian coals- some physico-chemical considerations. Fuel, 65(8), 1042-1046.

Grewer, T. (1994): Thermal Hazards of Chemical Reactions (Industrial Safety Series). Elsevier Press. Amsterdam. Vol. 4. $444 \mathrm{p}$.

Guney, M. (1971): An adiabatic study of the influence of moisture on the spontaneous heating of coal. CIM Bulletin, 64, 3, 138-146.

Hodges, D.J. and Hinsley, F.B. (1964): The influence of moisture on the spontaneous heating of coal. The Mining Engineer, 123, 211-224.

Hu, S.R. and Jiang, D.C. (2000): The disaster of spontaneous combustion of coalbeds and countermeasure of prevention. The Chinese Journal of Geological Hazard and Control, 11, 4, 69-71.

Jones, J.C. (2001): Jones JC 'On the extrapolation of results from oven heating tests for propensity to self- 
heating'Combustion and Flame 124 334-336 (2001): Combustion and flame, 124, 334-336.

Kadioğlu, Y. and Varamaz, M. (2003): The effect of moisture content and air-drying on spontaneous combustion characteristics of two Turkish lignitesa. Fuel, 82, 13, 1685-1693.

Kim, A.G. (1995): Relative self-heating tendencies of coal, carbonaceous shales, and coal refuse. US Department of Interior, Bureau of Mines.

Küçük, A., Kadıoğlu, Y. and Gülaboğlu, M.Ş. (2003): A study of spontaneous combustion characteristics of a Turkish lignite: particle size, moisture of coal, humidity of air. Combustion and Flame, 133, 3, 255-261.

Li, X.C., Li, W.J. and Zhang, S.Z. (1998): Coal Mine Safety in China. Beijing: China Coal Industry Publishing House.

Li, Y.H. and Skinner, J.L. (1986): Deactivation of dried subbituminous coal. Chemical Engineering Communications, 49, 81-98.

Mahananda, A.R. (2014): Studies on spontaneous heating liability of some Indian coals and its protective measures (Doctoral dissertation).

Martínez, M., Márquez, G., Alejandre, F.J., Del Río, J.J. and Hurtado, A. (2009): Geochemical study of products associated with spontaneous oxidation of coal in the Cerro Pelado Formation, Venezuela. Journal of South American Earth Sciences, 27, 2-3, 211-218.

Medunić, G., Mondol, D., Rađenović, A. and Nazir, S. (2018): Review of the latest research on coal, environment, and clean technologies. Rudarsko-geološko-naftni zbornik (The Mining-Geology-Petroleum Engineering Bulletin), 33, 3, 13-21.

Miron, Y., Lazzara, C.P. and Smith, A.C. (1992): Cause of floor self-heatings in an underground coal mine (Vol. 9415). US Department of the Interior, Bureau of Mines.

Mohalik, N.K., Lester, E. and Lowndes, I.S. (2016): Review of experimental methods to determine spontaneous combustion susceptibility of coal-Indian context. International Journal of Mining, Reclamation and Environment, 31, 5, 301-332.

Nandy, D.K., Banerjee, D.D. and Chakravorty, R.N. (1972): Applications of Crossing Point Temperature for Determining the Spontaneous Heating Characteristics of Coals. Journal of Mines, Metals \& Fuels, 20, 2, 41-48.

Nandy, D.K., Banerjee, D.D., Banerjee, S.C. and Chakravorty, R.N. (1967): Effect of moisture on the self heating characteristics of coal. Journal of Mines, Metals \& Fuels, 15, 10, 297-301.

Nelson, M.I. and Chen, X.D. (2007): Survey of experimental work on the self-heating and spontaneous combustion of coal. Reviews in Engineering Geology, 18, 31-83.

Nordon, P. and Bainbridge, N.W. (1983): Heat of wetting of a bituminous coal. Fuel, 62, 5, 619-621.

Nugroho, Y.S., McIntosh, A. and Gibbs, B.M. (2000): Lowtemperature oxidation of single and blended coals. Fuel, 79, 15, 1951-1961.

Nugroho, Y.S., McIntosh, A.C. and Gibbs, B.M. (1998): Using the crossing point method to assess the self-heating behavior of Indonesian coals. In Symposium (International) on Combustion (Vol. 27, No. 2, pp. 2981-2989). Elsevier.
Panigrahi, D.C. and Saxena, V.K. (2001): An investigation into spontaneous combustion characteristics of coals using differential thermal analysis. In Proceedings, 7th International Mine Ventilation Congress, Krakow, Poland, 495-500.

Parr, S.W. and Hilgard, E.R. (1925): Oxidation of Sulfur as a Factor in Coal Storage. Industrial \& Engineering Chemistry, 17, 2, 117-118.

Ren, T.X., Edwards, J.S. and Clarke, D. (1999): Adiabatic oxidation study on the propensity of pulverised coals to spontaneous combustion. Fuel, 78(14), 1611-1620.

Riley, J.T., Reasoner, J.W., Fatemi, S.M. and Yates, G.S. (1987): Self-heating of coal in barges. Journal Article Department of Chemistry and Canter for Coal Science. Western Kentucky University. Bowling Green. Kentucky, 162-170.

Saffari, A., Sereshki, F. and Ataei, M. (2019): Evaluation effect of macerals petrographic and pyrite contents on spontaneous coal combustion in Tabas Parvadeh and Eastern Alborz coal mines in Iran. International Journal of Coal Preparation and Utilization, DOI: 10.1080/1939 2699.2019.1574261.

Saffari, A., Sereshki, F., Ataei, M. and Ghanbari, K. (2013): Applying rock engineering systems (RES) approach to evaluate and classify the coal spontaneous combustion potential in Eastern Alborz coal mines. Int. Journal of Mining \& Geo-Engineering, 47, 2, 115-127.

Saffari, A., Sereshki, F., Ataei, M. and Ghanbari, K. (2017): Presenting an engineering classification system for coal spontaneous combustion potential. International Journal of Coal Science \& Technology, 4, 2, 110-128.

Sasaki, K., Wang, Y., Sugai, Y. and Zhang, X. (2014): Numerical modelling of low rank coal for spontaneous combustion. Coal Operators> Conference. University of Wollongong. Australia, 344-349.

Sereshki, F., Vaezian, A. and Saffari, A. (2016): Evaluation of the effect of macerals on coal permeability in Tazareh and Parvadeh mines. Journal of Stratigraphy and Sedimentology Researches, 32, 2, 23-34.

Singh, A.K., Singh, R.V.K., Singh, M.P., Chandra, H. and Shukla, N.K. (2007): Mine fire gas indices and their application to Indian underground coal mine fires. International Journal of coal geology, 69, 3, 192-204.

Smith, M.A. and Glasser, D. (2005): Spontaneous combustion of carbonaceous stockpiles. Part II. Factors affecting the rate of the low-temperature oxidation reaction. Fuel, 84, 9, 1161-1170.

Sondreal, E.A. and Ellman, R.C. (1974): Laboratory determination of factors affecting storage of North Dakota lignite: computer simulation of spontaneous heating.[28 refs; graphs] (No. BM-RI-7887). Bureau of Mines, Grand Forks, N. Dak.(USA). Grand Forks Energy Research Lab.

Stott, J.B. (1960): Influence of moisture on the spontaneous combustion of coals. Nature, $54 \mathrm{p}$.

Thakur, P., Schatzel, S. and Aminian, K. (Eds.). (2014): Coal bed methane: From prospect to pipeline. Elsevier, 420 p.

Vance, W. E., Chen, X. D. and Scott, S. C. (1996): The rate of temperature rise of a subbituminous coal during spontane- 
ous combustion in an adiabatic device: the effect of moisture content and drying methods. Combustion and Flame, $106,3,261-270$.

Walters, A.D. (1996): Joseph Conrad and the spontaneous combustion of coal- part 1. coal preparation. Amsterdam B.V. Published in The Netherlands under license by Gordon and Breach Science Publishers. 17, 3-4, 147-165.

Wang, D.M., Xu-yao, Q., Xiao-xing, Z. and Jun-jie, G. (2009): Test method for the propensity of coal to spontaneous combustion. Procedia Earth and Planetary Science, 1, 1, 20-26.

Wang, H. and Chen, C. (2015): Experimental study on greenhouse gas emissions caused by spontaneous coal combustion. Energy \& Fuels, 29, 8, 5213-5221.

Wang, H., Dlugogorski, B.Z. and Kennedy, E.M. (2003): Coal oxidation at low temperatures: oxygen consumption, oxidation products, reaction mechanism and kinetic modelling. Progress in Energy and Combustion Science, 29, 6, 487-513.

Wang, X., Luo, Y. and Vieira, B. (2018): Experimental technique and modeling for evaluating heat of rewetting effect on coals> propensity of spontaneous combustion based on adiabatic oxidation method. International Journal of Coal Geology, 187, 1-10.

Wen, H., Zhang, F.Y., Jin, Y.F. and Liu, W.Y. (2011): Experiment research on effect of sulfur on characteristic parameters of coal spontaneous combustion. Saf Coal Mines, 42, $10,5-7$.

Wiese Jr, R.G., Powell, M.A. and Fyfe, W.S. (1987): Spontaneous formation of hydrated iron sulfates on laboratory samples of pyrite-and marcasite-bearing coals. Chemical Geology, 63, 1-2, 29-38.

Xian, X.F., Wang, H.T., Jiang, D.Y. and Liu, B. (2001): The summarization of the investigation on coal mine fire prevention and fire extinguishing techniques in China. Engineering Science, 3, 12, 28-32.

$\mathrm{Xu}$, J.C. (2001): Determination theory of coal spontaneous combustion zone. Beijing (PR China): China Coal Industry Publishing House.

Xuyao, Q., Wang, D., Milke, J.A. and Zhong, X. (2011): Crossing point temperature of coal. Mining science and technology (China), 21, 2, 255-260.

Yang, Y., Li, Z., Si, L., Gu, F., Zhou, Y., Qi, Q. and Sun, X. (2017): Study governing the impact of long-term water immersion on coal spontaneous ignition. Arabian Journal for Science and Engineering, 42, 4, 1359-1369.

Yuan, L. and Smith, A.C. (2012): The effect of ventilation on spontaneous heating of coal. Journal of Loss Prevention in the Process Industries, 25, 1, 131-137.

Yuan, L. and Smith, A.C. (2013): Experimental study on CO and $\mathrm{CO}_{2}$ emissions from spontaneous heating of coals at varying temperatures and $\mathrm{O}_{2}$ concentrations. Journal of loss prevention in the process industries, 26, 6, 1321-1327.

Zhang, J., Ren, T., Liang, Y. and Wang, Z. (2016): A review on numerical solutions to self-heating of coal stockpile: Mechanism, theoretical basis, and variable study. Fuel, 182, 80-109.

Zhao, H., Geng, X., Yu, J., Xin, B., Yin, F. and Tahmasebi, A. (2016): Effects of drying method on self-heating behavior of lignite during low-temperature oxidation. Fuel Processing Technology, 151, 11-18. 


\section{SAŽETAK}

\section{Simultani učinak vlage i pirita na spontano izgaranje ugljena analiziran metodama TPT i R7o}

Ugljen je stabilan izvor energije i ujedno najčešće korišteno fosilno gorivo za proizvodnju električne energije u svijetu. Unatoč brojnim koristima, eksploatacija ugljena sa sobom nosi i ozbiljne rizike kao što je spontano izgaranje (samozapaljenje) u rudnicima. Brojni čimbenici utječu na sklonost ugljena samozapaljenju. Pirit može povećati rizik samozapaljenja, a u kombinaciji s vlagom rizik dodatno raste. Takva kombinacija rijetko je opisana u literaturi. Stoga je ovim istraživanjem prikazano ubrzanje učinka reaktivnosti pirita i vlage na samozapaljenje. Oni su izmjereni primjenom točke prijelazne temperature (TPT) i testa R7o. U tu svrhu u Iranu je osmišljen i izrađen novi uređaj. Prikazani su eksperimentalni podatci brzine reakcije pri čemu pirit ima dvostruko djelovanje. Najprije katalizira oksidacijsku reakciju, a zatim u vlažnome okruženju i sam oksidira postajući tako sekundarni izvor topline te na taj način ubrzava samozapaljenje ugljena. Budući da oksidacija pirita troši vlagu, postoji zajednički učinak ubrzavanja zagrijavanja, a manje topline troši se na isparavanje vlage. Rezultati su pokazali da sadržaj pirita može linearno ubrzati proces spontanoga izgaranja ugljena, dok ga sadržaj vlage manji od 20 \% ubrzava, a veći od $20 \%$ usporava. Rezultati ovoga istraživanja korisni su pri procjeni i upravljanju spontanim izgaranjem ugljena u rudnicima.

\section{Ključne riječi:}

spontano izgaranje ugljena, vlaga, pirit, TPT, R70

\section{Authors contribution}

Amir Safari (Ph.D. Candidate): initialized the idea, completed literature review and participated in all work stages, such as providing coal samples, running experimental tests and data analysis. Farhang Sereshki (Full Professor): executed experimental tests, data analysis and test of its accuracy, and helped with field work. Mohammad Ataei (Full Professor): managed the whole process and supervised it from the beginning to the end. 